\title{
Moral Identity, Altruism and Meaning in Life in Teacher Candidates
}

\author{
Assist. Prof.Dr. Fatıma Firdevs Adam Karduz \\ Cumhuriyet University - Türkiye \\ ORCID: 0000-0003-1765-6287 \\ karduzfirdevs@cumhuriyet.edu.tr
}

\author{
Dr. Adnan Özbey \\ University of North Texas - USA \\ ORCID: 0000-0002-5198-8026 \\ adnanozbey@hotmail.com
}

\begin{abstract}
This study aims to identify relations among meaning of life, moral identity, and altruism levels of teacher candidates and whether they vary depending on some variables. Among the quantitative research methods, the relational screening model, a subtype of general screening model, was used in this study. The graduates and seniors studying in Izmir and Manisa provinces are the teacher candidates who participated in the study. The Meaning in Life Scale developed by Akın and Taş (2011) was used to measure perception of meaning in life, the Moral Identity Scale developed by Yllmaz and Yllmaz (2015) was used to measure moral identity, and the Altruism Scale developed by Ummet, Eksi and Otrar (2013) to measure the altruism levels of participants as data collection instruments. According to the results, the level of altruism of the female was found to be statistically and significantly higher than the male; however, there was no gender-based difference on the level of moral identity and the meaning of life. Furthermore, the meaning of life level of graduate teacher candidates was statistically and significantly higher than senior students; on the other hand, the altruism and moral identity levels of teacher candidates differed depending on their graduation status. Both statistical significance and positive correlation were found between teacher candidates' perception of meaning of life, moral identities and the altruism of level. Consequently, the moral identity and altruism levels of prospective teachers were found to be predictors of the meaning of life in a statistically significant manner.
\end{abstract}

Keywords: Moral identity, altruism, meaning in life, teacher.

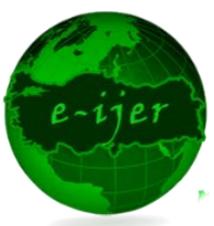

E-International Journal of Educational Research

Vol: 12, No: $5, p p .65-88$

Research Article

Received: 2021-09-26 Accepted: 2021-11-08

\section{Suggested Citation}

Adam Karduz, F.F. \& Ozbey, A. (2021). Moral identity, Altruism and Meaning in Life in Teacher Candidates, E-International Journal of Educational Research, 12(5), 65-88. DOI: https://doi.org/10.19160/eijer.1001101 


\section{INTRODUCTION}

The word "life" has probably been used since humankind started to use language. This consept has fundamental importance for all of us. However, we only have rough and subjective ideas about what life really means. The reason is that, until recently, it was easy for people to distinguish between what they call life and what they call non-life in the last century. There was no need for defining life exactly; its meaning could be understood intuitively. However, scientific development has given rise to complications about this issue (Klemke, 2000). Therefore, no one has been able to give a satisfactory and common answer to the question of the meaning in life since ancient times (Yalom, 2001). Many important figures in the field of philosophy have sought an answer to what renders life meaningful, even if they may not have put it into terms. Although some of these concepts are about happiness and morals, it is understood that a person has a life which (s)he needs to realize and contemplate (Metz, 2013).

The things that render life meaningful are, to some, making achievements (James 2005), having a moral character (Thomas 2005) or being devoted to relationships with family members (Velleman 2005). In a large majority of the studies conducted on the meaning of life, it was found out that showing the ultimate and positive value (s)he can exhibit is in the centre of an individual's life. In other words, relatively few people believe either that a meaningful life is an impartial quality or that the humankind or the universe as the main subject of interest, bears a meaning as a whole (Edwards 1972; Seachris 2009).

Indisputably, another component of the feeling of "meaningfulness" is the fact that it refers to altruism, a favour done without expecting anything in return unlike happiness or rightfulness conceptually (Wolf, 2010) because the pre-requisite of a meaningful life is that a person attains the objectives that fit his or her voluntary choice and self-sacrifice (Nielsen 1964) or because it involves gladness and wellness after doing this (Wohlgennant 1981). What makes life meaningful for individuals may vary. Reker and Wong (1988) defined the main sources of meaning as follows: (a) meeting basic needs such as food, shelter, and security; (b) leisure activities or hobbies; (c) creative work; (d) personal relationships (family or friends); (e) personal achievement (education or career); (f) personal growth (wisdom or maturity); (g) social and political activism (for example, promoting peace or participating in campaigns against environmental pollution); (h) altruism; (i) common values and ideals (truth, goodness, beauty and justice); (j) traditions and culture, including heritage or ethnocultural associations; ( $k$ ) legacy (leaving a mark for posterity); and (I) religion. These sources of meaning encompass different levels of needs, from basic biological needs to spiritual needs.

The meaning of life is not only achieving the objectives set but usage of high-quality, moral, altruistic attitudes that entail moral values and material and spiritual values more effectively (Taylor 1992). Young adults, who have developed a purposeful world view and have come to understand that their life has meaning, makes this meaning a sense of self and act in accordance with their resulting identity. In other worlds, embracing the identity is supporting the existence of meaning (Negru-Subtrica et al., 2016). Individuals can have meaningful and noteworthy experiences throughout their lives; however, such experiences can only be possible if individuals are committed to their personal goals and have the confidence and determination to take action to achieve them (Ugur \& Akin, 2015).

The transition period between adolescence and adulthood is the one where identity gets shaped (Erikson, 1968). Moreover, this period defines the process of forming meaning in life and sense of self. For this reason, positive identity development and making sense of life in young adults are considered to consolidate each other. Young adults should realize not only their own development but also social development in line with a moral objective (Malin, Ballard, \& Damon, 
2015). Young adults start to see themselves as individuals responsible for the world they live in and try to develop consistency and integrity in moral and personal terms as required by the social life by comprehending the complexity of the global world (Krettenauer et al., 2016; Hardy \& Carlo, 2011).

Moral aspect of a person is a central factor in defining his/her character and morals are one of the most critical determiners of identity development (Strohminger \& Nichols, 2014). Morals are deemed as the core factor in perceiving and assessing happiness among both ordinary people and psychologists (Phillips, De Freitas, Mott, Gruber, \& Knobe, 2017). Moral identity is explained as a motivating factor for the moral behaviour that helps determine whether an action that a person is to perform is right or wrong (Blasi, 2013; Freeman, Aquino, \& McFerran, 2009; Reed, Aquino, \& Levy, 2007). Of course, identity formation can occur in many dimensions such as religious, career or academic identity as well as moral one and identities in such multiple areas affect being well and establishes a prudent personality (Hardy et al., 2013; Meca et al., 2017).

Moral identity development comes to forefront among young adults due to cognitive and social development features. While children try to act morally in fear of punishment or for the sake of a reward, adolescents are, to a large extent, motivated by internal factors (Hardy \& Carlo, 2011). Internal factors such as having compassion, upholding justice, altruism, modesty, being responsible and selflessness reflect the behaviours of a person with moral identity qualities. The driving force of altruistic behaviour, which constitutes an important factor of moral identity, is neither central authority and official sanctions nor high social status or gaining personal interest (Griskevicius et al., 2010) but only increasing benefits provided by other people (Hamilton, 1972).

According to Buss (2008), the problem in explaining altruism is the fact that altruistic behaviours always existed in history of humankind. In other words, it is not an unusual situation. Durrant and Ward (2013) argued that altruistic behaviour is a norm of positive social behaviour. The important critical point in altruistic behaviour is not whether the helping behaviour is important for the helped person or not, but genuine intent of the helper (Freedman, Sears \& Carlsmith, 1993). According to Piliavin and Charning (1990), altruism occurs when a person puts the needs and expectations of others before his/her own expectations, desires and needs, when (s)he prefers to act in this direction.

Examination of altruism in terms of gender reveals a variance due to the difference between the two genders in their motives on helping. Since women are known to be more sensitive as compared to men, they are found to have higher levels of altruism. It has also been noted that there are studies indicating that men can share their income more equally with others (Johnson, 2000). Levels of altruism differ based on gender. Altruism levels in women have been found to be higher than that of men. (Duman, B.; 2021). Some other studies have found no meaningful variance in the level of altruism across genders, or any such relationship that could be attributed to gender difference, though (Kasapoglu, 2013; Onatir, 2008; Yesilkayall, 2015; İsmen and Yildiz 2005; Ak, 2013)

Levels of altruism have not found to be different across college majors (Duman, B. 2021). On the other hand, Boylu found in his (2020) study that social services majors had higher levels of altruism than students majoring in psychology. Throughout college life, students expand and strengthen their social circles and also develop a relationship of trust over time. Therefore, seniors normally are expected to indicate higher levels of altruism.

As people get more and more mature, they become more sophisticated in sympathizing with the subjective experiences of others and helping them (Farsides, 2007). A person starts learning as soon as (s)he opens his/her eyes to the world and this learning experience, which grows exponentially by experience throughout one's life, continues until the person's last breath. The first education starts at home, but education for social life is delivered by teachers, who are self-sacrificing, devoted and altruistic. It is generally thanks to our teachers that individuals who 
act in line with moral rules, are altruistic, virtuous, and honest are raised. Teaching is a sacred profession that should be performed through devotion, not appointment. Therefore, candidate teachers, who will step into the profession of teaching, should have developed moral identities, they should know how to live life without missing it, live it to the fullest and should be able to render their lives meaningful. Altruistic attitudes and behaviours should be a part of their personalities as well.

There is a vast amount of literature on moral identity (Hardy \& Carlo, 2011; Hart, 2005; Blasi, Kurtines, \& Gewirtz, 1994; Reimer \& Wade-Stein, 2004; Kocabiyik, 2014; Onat, 2011; Coşkun, 2017) and altruism (Batson, 2011; Nagel, 1978; Fehr \& Fischbacher, 2003; Arpacı \& Özmen, 2014; İşmen \& Yıldız, 2005). Few studies have been published on the relationship between moral identity and altruism (Yang, Cai, Yong, \& Shi, 2020; Özbey \& Karduz, 2018. However, the literature is thought to fail to reflect the relationship between moral identity, altruism, and the meaning of life concepts. Therefore, this study holds an importance in terms of making a new contribution to the literature.

This study examines moral identity, meaning in life and altruistic behaviour attitudes in teacher candidates according to different variables. To this end, answers were sought for the following questions:

1. Do moral identity, meaning of life and altruistic behaviour attitudes of teacher candidates differ statistically at a significant level depending on gender?

2. Do moral identity, meaning of life and altruistic behaviour attitudes of teacher candidates differ statistically at a significant level depending on graduation status?

3. Is there a meaningful correlation among moral identity, meaning of life and altruistic behavior attitudes of teacher candidates statistically at a significant level?

4. Do moral identities and altruistic behavior attitudes of teacher candidates predict life at a significant level statistically?

\section{METHODOLOGY}

In this study, correlational research design, a subtype of general survey model, was used. General survey moldes are arrangements made on the whole population or a group or a sample to be taken out of a population that consists of great number of elements for the purpose of reaching a general conclusion about the population. Single can be performed by general screening models. Correlational research design is a research model that aims to determine the existence and/or degree of covariance between two or more variables (Christensen, Johnson, Turner, \& Christensen, 2011; Seeram, 2019). This study aims to identify potential relations among meaning of life, moral identity and altruism levels of teacher candidates and whether they vary depending on some variables.

\section{Study Group}

The convenient sampling method (Büyüköztürk et al., 2015) was utilized. For this purpose 166 (44.1\%) graduates and 209 (55,9\%) seniors studying in İzmir and Manisa provinces, which totaled 375 teacher candidates were recruited for the study. At the first stage, scales were evaluated separately and forms of 8 teacher candidates with incorrect or incomplete scales were taken out of the sample. As a result of this, forms of 196 (53,4\%) female students and $171(46,6 \%)$ male students totaling 367 senior and graduate teacher candidates were included to evaluation of the study group. Ages of the participants ranged from 21 to 26 and the average age of the participants is 23.66 . 


\section{Data Collection Instruments}

The Meaning in Life Scale (MLS): The meaning in life scale was developed by Steger et al., (2006) for the purpose of determining the meaning people find and seek in life. Adaptation to Turkish was performed by Akın and Taş (2011). The Scale is 7 point Likert ( 1 for definitely not valid-7 for definitely valid) type measurement instrument and comprises of 10 items. The scale consists of two sub-scales: the current meaning and the meaning sought in life. Cronbach's alpha reliability coefficient of the scale was found to be .77 for the current meaning subscale, .83 for the sought meaning subscale and .81 for the whole scale. It was determined that test-retest reliability coefficients obtained at an interval of four weeks was .89 for current meaning scale, .92 for sought meaning scale and .94 for the whole scale. Cronbach's alpha reliability coefficient was calculated as $.81 \mathrm{for}$ the whole scale in the present study.

Moral Identity Scale: Moral Identity Scale, which was developed by Aquino and Reed (2002) to measure moral identity levels of individuals consists of 10 items and two sub-dimensions in total: Symbolization (5 items), internalization ( 5 items). The scale was adapted into Turkish by Yılmaz and Yılmaz (2015). Cronbach's alpha reliability coefficient of the scale was found to be .77 for internalization sub-dimension and .76 for symbolization sub-dimension. Corrected item total correlations of the scale range from .32 to .71. Fourth and seventh items of the internalization dimension are negative (reverse) items. In this study, Cronbach's alpha reliability coefficient was calculated as .76. for the whole scale.

Altruism Scale: It was developed by Ümmet, Ekşi and Otrar (2013) in order to measure altruism levels of individuals. Exploratory factor analysis was used in the scale development study, criterion validity was performed, item discrimination was determined and Cronbach's Alpha reliability number was calculated. A scale consisting of monetary aid (6 items), aid provided in traumatic conditions (6 items), aid provided to the old/sick (4 items), aid based on physical strength ( 5 items), aid in education process ( 5 items), aid arising from feeling of closeness (5 items) was obtained out of 7 sub-dimensions (participation in voluntary activities (7 items)) and 38 items that explain 51.82 of the total variance at the end of the study. As for Cronbach Alpha numbers that belong to sub-dimensions, Cronbach Alpha vale of the 1st factor was found to be $.815,2 \mathrm{nd}$ .776 , 3rd .757, 4th .760, 5th .743, 6th .696, 7th .659 and total Cronbach alpha value of the scale was found as .93. There is no reverse coded item in the scale. Cronbach's alpha coefficient of the scale was measured as .91 for the whole scale in this study.

\section{Process}

Meaning in life, moral identity and altruism variables were chosen carefully so as to determine the possible relation in this study, which is conducted. Then scales related to the variables and personal information form were combined in order to obtain main variables. The participants were informed about the purpose and importance of the application before starting the scale application, they were asked if they were voluntary and then application was performed on teacher candidates voluntary to be participants.

\section{Data Analysis}

After the data obtained was transferred to computer environment, the data were analysed by parametric tests (kurtosis and skewness values are between-1.96 and +1.96 (Tabachnick \& Fidell 2013). Data was analysed by SPSS- 25 package programme. Independent samples $t$ test was used for paired comparisons, Pearson moment multiplication correlation analysis for variable correlations, and regression analysis was used in order to identify the prediction level. $p<.05$ importance level was taken as basis as confidence interval (Altunışık, Coşkun, Bayraktaroğlu, Yıldırım, 2005). 
Kolmogorov-Smirnov statistical value was calculated as .043 ( $p>.05)$ for meaning in life, .067 $(p>.05)$ for moral identity and .078 ( $p>.05)$ for altruism. Kurtosis and skewness value was calculated as (1.2 and -0.9) for meaning in life, (1.1 and -1.09) for moral identity and (1.04 and 0.9) for altruism. Kolmogorov-Smirnov statistical value of the meaning in life scale came out a little lower than expected. Nevertheless, when considered according to kurtosis and skewness values (between -1.96 and +1.96 ), it was decided to conduct analyses by parametric tests.

\section{FINDINGS}

\section{Comparison Analyses}

Independent sample $t$ test was used in order to compare the meaning in life, moral identity and altruistic levels of teacher candidates by gender variable and findings were shown in Table 1.

Table 1. T Test Results of Meaning in Life, Moral Identity and Altruism Levels of Teacher Candidates $(N=367)$

\begin{tabular}{lcccccc}
\hline & Gender & $\mathbf{N}$ & $\overline{\mathrm{x}}$ & SD & t & p \\
\hline 1. Meaning in Life & Female & 196 & 51.16 &, 9048 &,- 484 &, 629 \\
& Male & 171 & 51.62 &, 8956 & & \\
2. Moral Identity & Female & 196 & 53.46 &, 9857 & 1,418 &, 157 \\
& Male & 171 & 51.90 & 1,1121 & & \\
3. Altruism & Female & 196 & 38.91 &, 5634 & 2,908 &, 004 \\
& Male & 171 & 37.22 &, 5520 & & \\
\hline${ }^{*} \mathrm{p}<05$ & & & & & &
\end{tabular}

As seen in Table 1, there is no statistically significant difference between meaning in life mean scores of female teacher candidates $(\bar{x}=51.16)$ and meaning in life mean scores of male teacher candidates $(\bar{x}=51.62)(t=-, 484, p<.05)$. Similarly, there is no statistically significant difference between moral identity mean score of female teacher candidates $(\bar{x}=53.46)$ and moral identity mean score of male teacher candidates $(\bar{x}=51,90)(t=1,418, p<.05)$. On the other hand, altruism mean score of female teacher candidates $\bar{x}=38.91)$ is significantly higher than that of male teacher candidates $(\bar{x}=37,22)$ in statistical terms $(t=2,908, p<.05)$.

Independent sample $t$ test was used in order to compare meaning in life, moral identity and altruism levels of teacher candidates according to graduation status and findings were shown in Table 2 .

Table 2. T Test Results of Meaning in Life, Moral Identity and Altruism Levels of Teacher Candidates by Graduation Status ( $N=367)$

\begin{tabular}{lllllll}
\hline & Grade & N & $\bar{x}$ & SD & t & p \\
\hline 1. Meaning in Life & Senior & 205 & 50.27 &, 9034 & $-2,674$ &, 008 \\
& Graduate & 162 & 52.77 &, 8776 & & \\
2. Moral Identity & Senior & 205 & 52.17 & 1,0478 & $-1,170$ &, 243 \\
& Graduate & 162 & 53.46 & 1,0460 & & \\
3. Altruism & Senior & 205 & 38.32 &, 5744 &, 731 &, 465 \\
& Graduate & 162 & 37.88 &, 5508 & & \\
\hline
\end{tabular}

${ }^{\star} \mathrm{p}<.05$

As can be seen in Table 2, meaning in life mean score of graduate teacher candidates ( $\bar{x}$ $=52.77)$ is statistically higher than meaning of life mean scores of senior teacher candidates $(\bar{x}$ $=50.27)$ at a significant level $(t=-2,674, p<.05)$. There is no statistically significant difference between moral identity mean score of senior teacher candidates $(\bar{x}=52.17)$ and moral identity 
mean score of graduate teacher candidates $(\bar{x}=53.46)(t=-1,170, p<.05)$. Similarly, there is statistically no significant difference between altruism mean score $(\bar{x}=38.32)$ of senior teacher candidates and those of graduate teacher candidates $(\bar{x}=37,88)(t=.731, p<.05)$.

\section{Findings on Correlation}

Pearson moments multiplication correlation analysis was implemented in order to find out if there is correlation among meaning in life, moral identity and altruism levels of teacher candidates and results were shown in Table 3.

Table 3. Pearson Correlation Matrix about the Correlation among Meaning in Life, Moral Identity and Altruism Levels of Teacher Candidates

\begin{tabular}{lllllll}
\hline Variables & N & ML & MI & A & $\bar{x}$ & SD \\
\hline 1-Meaning in Life & 367 & - & $.436^{\star *}$ & $.305^{\star *}$ & 25.69 & 1,0390 \\
2-Moral Identity & 367 & - & - & $.280^{\star *}$ & 52.74 & 1,0475 \\
3-Altruism & 367 & - & - & - & 38.12 &, 5638 \\
\hline${ }^{* *} \mathrm{p}<.01$ & & & & &
\end{tabular}

As is seen in Table 3, a statistically significant positive correlation exists at $p<.01$ threshold among meaning in life, moral identity and altruism. Accordingly, the correlation coefficient between meaning in life and moral identity is $r=.44$, between the meaning in life and altruism is $r=.31$, and between moral identity and altruism is $r=.28$.

Multiple regression analysis was carried out in predicting the meaning in life for teacher candidates so as to see the role of moral identity and altruism variables and the results were shown in Table 4.

Table 4. Results Relating to Meaning in Life, Moral Identity and Altruism in Teacher Candidates

\begin{tabular}{lccccc}
\hline & \multicolumn{2}{c}{ Unstandardised Coefficients } & \multicolumn{3}{c}{ Standardized coefficients } \\
\hline Model & B & SH & $\boldsymbol{\beta}$ & $\mathbf{t}$ & $\mathbf{p}$ \\
\hline (Fixed) & 5,958 &, 364 & & 16,369 &, 000 \\
Moral Identity &, 378 &, 048 &, 381 & 7,911 &, 000 \\
Altruism &, 366 &, 089 &, 199 & 4,129 &, 000 \\
\hline $\mathrm{p}<.001$ & & & & &
\end{tabular}

It is seen in table 4 that moral identity and altruism variables predict meaning in life at a statistically significant level in the regression analysis carried out for the purpose of revealing the role of moral identity and altruism variables in prediction of meaning in life $(F=53,105, p<.001$, $\mathrm{R}=.48, \mathrm{R} 2=.23$ ). According to the results of this analysis, contribution of the variables in variance is 23. Contribution of moral identity and altruism in variance (Moral Identity: $\beta=.381, t=7,911$; Altruism: $\beta=.199, t=4,129, p<.001$ ) was found to be significant.

\section{CONCLUSION, DISCUSSION and RECOMMENDATIONS}

\section{Conclusion and Discussion}

In this study, findings obtained were assessed in order to examine moral identity, meaning in life and altruistic behavior attitudes in teacher candidates according to different variables.

First of all, when moral identity, meaning in life and altruistic behavior attitudes of teacher candidates are considered according to gender, no statistically significant difference exists between meaning in life score averages of female teacher candidates and those of male teacher 
candidates. In other words, meaning in life does not differ depending on gender. There are studies in the literature where similar results had been reported (Kiang \& Fuligni, 2010; Demirbaş, 2010; Yüksel, 2013). As a matter of fact, in the study he conducted with two different study groups, Yüksel (2013) found that meaning in life did not differ among university students depending on gender. It was found by the same token in the study of Baş and Hamarta (2014) that meaning in life did not vary depending on gender and that meaning in life scores of female and male participants were quite close. Studies that have reached different conclusions are also seen in the literature. In a scale study by Steger et al., (2006), it was found that meaning in life differed by gender. Taş (2011) reached the conclusion that teachers differed according to gender in meaning sought in life sub-dimension. It was revealed that meaning sought in life levels of male teachers were higher than those of female teachers. The reason why meaning in life does not differ depending on gender in the current study is the fact that if a person believes in something, whatever (s)he places in the centre of his/her life or whatever (s)he desires to reach is meaningful. For this reason, it can be purported that generally, the purpose of existence of a person matters and gender has no impact on that. In other words, it can be assumed that meaning in life may differ from person to person depending on changeable state of mind of each individual. In general terms, it can make a person's life more meaningful if that person gets what (s)he strongly wants, attains his/her high objectives or do whatever (s)he believes to be important (Trisel 2002; Hooker 2008; Alexis 2011). According to the subjectivist point of view, if a person cares about or likes a situation mentally, it bears a meaning for that person to the extent that life cares about or likes it (Frankfurt, 2009).

By the same token, no statistically significant difference was found between moral identity score averages of female teacher candidates and those of male teacher candidates. When the literature is taken into account, it is seen that there are studies that have reached different conclusions. Walker (1984) reported that men exhibit a higher moral development level in adulthood compared to women in his study where he examined gender difference in Kohlberg's moral development theory. In Arnold's study (1993), it was concluded that women felt more close to moral features and get more motivated by things related to morals than men. While women stated that helpfulness bears more importance then adapting to the surroundings in moral terms, men expressed the opposite.

Moreover, moral identity and moral motivation contribute significantly to prediction of moral behavior according to the result of the study. In the study they conducted about moral development, Kumru, Carlo and Edwards (2004) concluded that while men tend to exhibit positive social behavior publicly, women rather tend to exhibit emotional, obedient and secret positive social behaviors. Besides, it was concluded that while peer attachment and communitarian values predict positive social public behavior, parental and peer attachment predict emotional positive social behavior. It followed that communitarian values and empathy predicted altruistic positive behavior and obedient and secret positive behaviors. This may result from the fact that the male gender role requires them to be in a social environment more under the social gender role and therefore they place more importance on their responsibilities as they consider friendship and social relationships significant (Beutel and Marini, 1995) and have competitive, assertive, bold, hunter-collector, breadwinner, strong and protective attitudes. It can also be thought that while women exhibit moral behavioral patterns where they fulfil their responsibilities in a personal relationship, men tend to make judgements on morality of an action provided that it is accepted by the society and complies with social rules. In other words, it can be argued that women exhibit moral behaviors rather in emotional relationships with obedient and positive social behaviors while men exhibit moral behaviors rather in social relationships (Kumru, Carlo and Edwards, 2004).

On the other hand, it was seen that altruism mean score of female teacher candidates were statistically higher than those of male teacher candidates at a significant level. Given the literature, it is observed that the finding obtained is confirmed by some study results (Coulter and et al., 
2007; Rushton, Fulker, Neale, Nias and Eysenck, (1986); cited in Işmen and Yıldız, 2005). In the studies concerned, it was stated that women reported higher level of altruistic attitude compared to men. Again, in the research where he reviewed 16 studies, Hoffman (1977) indicated that women showed higher level of emotional reaction and helpfulness to feelings of others. This can be attributed to the fact that women are more inclined to altruistic attitude in comparison to men in terms of gender roles within the society, which is the social living space. As a matter of fact Eagly and Crowley (1986) revealed that, in connection with gender role, men help others more in dangerous situations or in cases that require physical strength while women have higher protective tendency as they exhibit more emotional approach in such cases as special responsibility projects and helping the disabled, which require emotional and safe environment. Altruistic attitude level of women was found to be higher than men in the study conducted by Eğilmez and Naylor (2017) as well. It can be thought that this stems from the fact that women tend to be more emotional, supportive and personally open in their relationships and have higher sense of kindness, mercy, responsibility and devotion (Beutel \& Marini, 1995).

Gender sociaization might be another reason. Gender socialization is the process through which children learn about social expectations, attitudes, and behaviors typically associated with boys and girls. That is, as children grow, they build a general sense of self and the ability to relate to others and play a role in society. In this process, they develop beliefs about roles and expectations associated with each gender group (gender roles) and a self-identity (gender identity) as a member of one gender group or another (Stockard, 2006). In this vein, girls who learn about the role of motherhood and emotions at a younger age by playing with rag babies might have instinctively more self-sacrificing, moderate, maternal and protective attitudes due to their potentials of becoming mothers. As a matter of fact, in the study they conducted, Walker and Frimer (2007) concluded that personalities who exhibit examples of affection are more merciful, altruistic, productive and optimistic when compared to people exhibiting examples of boldness.

However, some studies do not support the conclusion reached in this study (Kaçar-Banbal, 2010; Krebs, 1970; İşmen \& Yıldız, 2005; Ma and Leung, 1992; Onatır, 2008). The data obtained from the research performed by Harris and Bays (1973) with 80 male and 80 female shopping customers show that men have higher probability of helping women who wear femininely especially if they ask for a feminine help. No correlation was found between altruistic attitude and gender in some studies. In addition to no correlation was found between altruistic behavior and gender performed with children. Again, no significant difference was found among altruistic levels of students in the study Kasapoğlu (2014) conducted with university students. The reason for this may be that, depending on the gender role assigned to men and women, men tend to help other people in dangerous and risky situations (Eagly \& Crowley, 1986) whereas women exhibit more emotional help and protective behaviors in safe and secure situations (Duru, 2002). Another reason is that men desire to earn more money and rise in their profession because they take on the responsibility of providing financial livelihood of their families (Fortin, 2006), and women exhibit more altruistic behavior due to their traditional roles and responsibilities such as child care and support for their spouses.

Secondly, when moral identity, meaning in life and altruistic behavior attitudes of teacher candidates are considered according to their graduation status, it is seen that meaning in life mean score of graduate teacher candidates is statistically higher at significant level than those of senior teacher candidates. When the literature is examined, it is seen that studies reaching different conclusions exist. The study carried out by Malin, Reilly, Quinn and Moran (2014) quantitatively demonstrated that young adults have lost their living purposes more than high school students. According to the study conducted by Han, Liauw and Kunt (2019), the existence level of meaning in life drops in adulthood. Similarly, the study of Malin et al. (2017) indicated that as civilians after graduation from high school, individuals show decreasing tendency to participate 
in activities that demonstrate existence of purposes related to meaning of life. The reason is that the period of adulthood is risky in establishment of purpose and meaning of life as adulthood period corresponds to times of fundamental changes and pre- and post-high school (university education) period correspond to transition to an independent life (Smith, Christoffersen, Davidson, \& Herzog, 2011). Given the increasing search for meaning and purpose in this period (Bronk, Hill, Lapsley, Talib and Finch, 2009; Steger, Oishi and Kashdan, 2009), it can be said that the decrease in existence of meaning in life occurred in the period of long-term period of search for meaning. In other words, this can result from the fact that teenagers at the age of high school and university see things through rose-coloured glasses as they have not yet faced the challenges of life and they have the protection and support of their families behind them. It may be becoming hard to maintain the existence of meaning of life upon stepping into the professional life, where they have to stand on their own two feet and have increased responsibility. However, no significant difference was found statistically between moral identity mean score of senior teacher candidates and graduate teacher candidates. When the literature is reviewed and the studies on the changes caused by the social environment of university in individuals are examined, it is seen that in the study they carried out, King and Mayhew (2002) indicated that development of moral judgement skills of university students did not only stem from chronological maturing. According to the finding of the study, education received in university is effective on development of the self. Individuals graduating from university may experience problems in both their personal lives and in finding a solution to the moral dilemmas they encounter in their professional lives. Based on this fact, universities should explore preparing their students for the moral dilemmas they will be faced with in their personal and professional lives as indicated by Curtis-Tweed (2004). In his study on self-perception and moral examples conducted with 120 adults aged 17-91, Walker (1999) found the compatibility dimension as a characteristic feature in young adults (adults at university age) setting a moral example. Likewise, in their study entitled "Young Adult Moral Exemplars: Making of Self through Stories" Matsuba and Walker (2005) made interview with equal number of male and female young adults with a mean age of 25 . When the young adults in the study group were compared, it was concluded that intermediary themes, saviour experiences, scenes of getting dirty, awareness about pains of others, enemies, ideological depths and future objectives are different in terms of moral examples. In a study conducted on adults, Colby and Damon (1992) found that these behaviors are deemed as an emotional requirement rather than behaviors that surface upon contemplation. Similar results were obtained in the studies conducted with young adults at university age. In the study he carried put, Nickerson (2003) investigated the relation between the adolescents' moral sense of self and their moral reasoning skills. According to the result of the research, a correlation exists between moral sense of self and reduction of risk behavior. This study demonstrates that moral sense of self is an important aspect of moral identity.

Similarly, there is no statistically significant difference between altruism mean score of senior teacher candidates and those of graduate teacher candidates. Similar findings can be seen when the literature is examined. In his research where he examined the altruism levels of nursing seniors, Kaçar- Banbal (2010) found no significant difference in class levels of students and total altruism score. However, it is also seen that there are studies that have reached different conclusions. It was observed in the study of Kasapoğlu (2014) that junior students had significantly higher level of altruism than freshman students. In the research by İşmen and Yıldız (2005), it was found that those working as teachers were more altruistic than those who were yet teacher candidates. This may stem from the fact that those starting teaching understand how important altruism is and realise how big of a pleasure it gives to do their students favours without expecting nothing in return.

According to the other finding obtained, there is a statistically significant positive correlation among meaning in life, moral identity and altruism levels of teacher candidates. Accordingly, the correlation coefficient was found between meaning in life and altruism, and 
between moral identity and altruism. Moral identity is significantly related to development of humans and pro-social and positive social behavioral tendency that form moral aspects of life (Han, 2015; Kristjánsson, 2007). Moral identity is the standards where the concepts of morality (for example kind, fair, pro-social behaving and altruism) are central, important and necessary for the person's own identity (Blasi 1984). There are two important forms of pro-social behaviors, one of which is altruism. A person who exhibits altruistic behavior has to pay a certain price. The altruistic behavior should be exhibited in return for this price without expecting any personal interest (Bilgin, 2020). As a general rule, it was reported as a result of the identity research that a person acts morally while taking into account both altruistic and informal behaviors (Stets\&Carter 2011; 2012).

Aquino and Reed (2002) conceptualizes moral identity as a structure that enables relationship of a person with other people through a series of moral behaviors that define his/her moral self and personality and that regulates itself. Altruism is a type of moral behavior according to the identity theory as well. For example, individuals with important moral identities exhibit more positive attitudes in terms of efforts of aid for others (Reed \& Aquino 2003). Moreover, according to Patrick et al., (2018), moral identity affects willingness of adult individuals to show pro-social behaviors (in other words, altruistic attitude). However, little importance was placed on internalization of pro-social behavior types in adolescence and the roles and correlations among such factors as moral identity and moral judgment. Patrick et al. (2018) found in their study that moral identity provides for most pro-social behavior (altruistic attitude) types. Moral judgement and moral identity provide for altruistic and pro-social behaviors collectively and correlationally. Moreover, moral identity has mediated the relations among moral judgment and some social behavior forms (helpfulness, voluntariness) Le Galliard et al. (2003) found that altruistic behavior has various prices but individuals with developed moral identity decrease these prices and become less selfish in time. Midlarsky (1991) places the benefits provided by altruism to individuals under five items: it helps the individual to get away from his/her own problems, develops perception on the value and meaning of life, improves empathy skills, heals the soul and increases his/her psychological mood, socialization and well-being. In the study conducted by Kasapoğlu (2014), it was found that there is a positive and meaningful correlation between wellbeing and altruism levels of students and that altruism is a significant predictor of well-being. For this reason, meaning in life contains positive social behaviors. In other words, altruistic attitude includes the elements of bringing meaning into one's life and helping people.

Moreover, altruism has positive gains such as setting an example for future generations with self-sacrificing and moral behaviors, increasing social status, psychological well-being, bringing meaning into life and improving reputation in social environment (Buss, 2015). It can be asserted that this results from the fact that a teacher candidate who has high moral identity and altruistic behaviors generally has increased potential of exhibiting altruistic behaviors that can set an example for future generations with self-sacrificing and moral behaviors, helping others, especially students; therefore, feels him/herself happy as (s)he helps others, bringing meaning into his/her life. Hence, it can be argued that there is positive correlation among meaning in life, moral identity and altruism and they underpin each other.

Finally, it is observed that moral identity and altruism variable predict the meaning of life at a statistically significant level in the regression analysis conducted for the purpose of seeing the role of the variable of moral identity and altruism in predicting meaning of life in teacher candidates. According to the results of this analysis, contribution of the variables in the variance is $22 \%$. The contribution of moral identity and altruism in variance was found meaningful. Individuals who grasp the meaning and importance of life and try to make their existence in life meaningful spend life more positively and fully (Zika and Chamberlain, 1992). Meaning in life, which is one of the fundamental concepts of positive psychology, bears great importance for teachers, who shape the future and students, who own it. Teacher candidates who cannot give 
meaning to their lives cannot be successful in materializing their future objectives and they might also experience serious difficulty in setting an example for the students entrusted to them and in shaping their lives when they start performing their jobs (Lindeman and Verkasalo 1996). However, teacher candidates who find life meaningful, bear positive feelings in their university education period, are altruistic and have dreams related to their profession and they also experience no difficulty in making both themselves and the ones around themselves happy and satisfied (Hicks and King, 2007).

When the literature is scanned, it was reported in the longitudinal research conducted that there is a mutually reinforcing relation between meaning in life and moral identity development (Negru-Subtirica, Pop, Luyckx, Dezutter, \&Steger, 2016). In this vein, another research carried out demonstrated that moral identity is positively correlated to activities that increase the meaning of life such as participation in social responsibility activities, exhibiting altruistic behaviours and joining voluntary activities (Porter, 2013). In the study conducted by Han, Liauw and Kunt (2019), it was reported that while moral identity predicts existence of meaning positively, existence of meaning does not have an important effect on moral identity. In other words, the factors that makes life meaningful do not have a positive or negative effect on the thing that renders a person's life meaningful (Steger et al., 2006). To put it in a different way, young adults may build the meaning of their lives in ways that are not directed at any moral purpose like finding meaning as a star athlete or student. Therefore, the sole existence of meaning does not necessarily define moral identity. On the other hand, developing a moral identity provides for existence of meaning of life (Han, Liauw and Kunt, 2019). In their study, Yıkılmaz and Demir-Güdül (2015) demonstrate that conscious awareness and existence of meaning in life define satisfaction in life at a significant level in university students while the search for meaning is not a meaningful predictor of satisfaction in life.

Moral behavior ensures order and security in the society (Stets\& McCaffree, 2014). Teachers can convey moral behavior to their students to the extent that they internalize it as a code and adapt it into their lives. In this way, morals of the society can be preserved. Perpetuity of moral order can be sustained by the actions of future generations. The truth is, people are not cruelly selfish but if this situation gets normalized or students are raised in societies that have the morality to behave selfishly, they may learn to be so (Basu,2007). If we desire to hand the world over to a future generation that have a moral identity, it may be argued that especially teachers should support the set of socially inherent values such as consciousness, altruism, integrity and fairness.

\section{Recommendations}

This study is limited to senior and graduate teacher candidates. In other words, it is not possible to extend the findings obtained to other university education levels and other groups of profession. Conducting similar studies with various variables and students of different departments and grades and making comparisons with different groups of profession may add a different perspective to the matter. The psychological counsellors, psychologists and social service experts that work actively in the field may help university students and graduate profession candidates to gain consciousness by using these findings in the education programmes and seminars and by informing them.

According to the findings obtained from the study, altruism makes the lives of teacher candidates meaningful. In this respect, making changes in the education programs will be beneficial for teacher candidates, who attach importance to sharing, helping and cooperation, and can approach their students with compassion and altruism, to develop altruistic behaviors and increase their inclinations during their educational processes.

Teacher candidates are role models in terms of knowledge, morality and personality. In the education process of teacher candidates, attaching importance to moral education and 
personality development along with academic knowledge, and considering values while planning this process are recommended.

This study was limited to senior university students, graduate students and certain universities. Covering a larger sample including different universities and regions in Turkey might lead to different results.

\section{REFERENCES}

Acar, M. C. Ve Apak, H. (2017). Sosyal Hizmet Bölümü Öğrencilerinin Empatik Eğimleri Ille Özgecilik Düzeyleri Arasındaki Ilişkinin İncelemesi. Toplum ve Sosyal Hizmet Dergisi, 28(1), 93- 112.

Akın, A. \& Taş, İ. (2011). Validity and reliability of the Turkish version of the meaning in life questionnaire. III. International Congress of Educational Research. Girne, TRNC.

Ak, K. (2013). Üniversite Öğrencilerinin Özgecilik Düzeylerinin Yordayıcısı Olarak Yaşam Amaçları. Yüksek Lisans Tezi, Gazi Osman Paşa Üniversitesi Eğitim Bilimleri Enstitüsü, Tokat.

Alexis., A. (2011). The meaning of life: A modern secular answer to the age-old fundamental question. Create Space Independent Publishing Platform.

Altunışık R., Coşkun R, Bayraktaroğlu S., \& Yıldırım E. (2005). Sosyal bilimlerde araşııma yöntemleri SPSS uygulamalı. Sakarya Kitabevi. Sakarya.

Aquino, K. \& Reed, A. (2002). The self-importance of moral identity. Journal of Personality and Social Psychology, 83(6), 1423-1440. https://Doi.Org/10.1037//0022-3514.83.6.1423

Arnold, M. L. (1993). The place of morality in the adolescent self. Harvard University.

Arpaci, P., \& Ozmen, D. (2014). The relationship between levels of altruism and empathic tendencies among nursing students/Hemsirelik ogrencilerinin ozgecilik ve empatik egilim duzeyleri ve aralarindaki iliski. Journal of Education and Research in Nursing, 11(3), 51-58.

Baier, K. (1997). Problems of life and death: A humanist perspective. Amherst: Prometheus Books.

Basu, K. (2007). Identity and altruism: The moral basis of prosperity and oppression. Mimeo, Cornell University.

Baş, V. \& Hamarta, E. (2014). Üniversite öğrencilerinde değerler ve yaşamın anlamı arasındaki ilişki. Değerler Eğitimi Dergisi, 13(29), 369-391.

Batson, C. D. (2011). Altruism in humans. Oxford University Press, USA.

Batson, C. D., Dyck, J. L., Brandt, J. R., Batson, J. G., Powell, A. L., McMaster, M. R., \& Griffitt, C. (1988). Five studies testing two new egoistic alternatives to the empathy-altruism hypothesis. Journal of Personality and Social Psychology, 55(1), 52. https://Doi.Org/10.1037/0022-3514.55.1.52

Beutel, A. M., \& Marini, M. M. (1995). Gender and values. American Sociological Review 60(3), 436-448. https://doi.org/10.2307/2096423

Bilgin, A. (2020). A philosophical analysis of the biological accounts of morality and altruism (Master's thesis).

Blasi, A. (1984). Moral identity: Its role in moral functioning in morality, moral behavior, and moral development (ed. William Kurtines and Jacob Gewirtz). New York: Wiley, 128-39.

Blasi, A. (2013). The self and the management of the moral life. In handbook of moral motivation (pp. 229248). Rotterdam: Sense Publishers. https://Doi.Org/10.1007/978-94-6209-275-4_14.

Blau, P. M. (1964). Exchange and power in social life. New Brunswick, NJ: Transaction Publishers. 
Boylu, M. A. (2020). "Üniversite Öğrencilerinin Özgecilik Düzeyleri İle Empatik Eğilim Ve Benlik Saygısı Arasındaki İlişkinin Incelenmesi". Yüksek Lisans Tezi, Çağ Üniversitesi Sosyal Bilimler Enstitüsü, Mersin.

Brassai, L., Piko, B. F., \& Steger, M. F. (2011). Meaning in life: Is it a protective factor for adolescents' psychological health? International Journal of Behavioral Medicine, 18(1), 44-51. https://Doi.Org/10.1007/s12529-010-9089-6.

Britton, K. (1969). Philosophy and the meaning of life. Cambridge: Cambridge University Press.

Bronk, K. C., Hill, P. L., Lapsley, D. K., Talib, T. L., \& Finch, H. (2009). Purpose, hope, and life satisfaction in three age groups. The Journal of Positive Psychology, 4(6), 500-510. https://Doi.Org/10.1080/17439760903271439.

Buss, D. M. (2008). The evolution of desire-revised. NY: Basic Books.

Buss, D. M. (2015). Evolutionary psychology: The new science of the mind. NY: Psychology Press.

Buyukozturk, S., Kilıc Cakmak, E., Akgun, O.E., Karadeniz, S., and Demirel, F. (2012). Bilimsel araştırma yöntemleri. Ankara: Pegema Akademi.

Christensen, L. B., Johnson, B., Turner, L. A., \& Christensen, L. B. (2011). Research methods, design, and analysis. (TWELFTH Edition) Pearson Education, Inc.

Colby, A., \& Damon, W. (1992). Some Do Care: Contemporary Lives of Moral Commitment. New York: Free Press.

Coşkun, A. (2017). Ahlaki kimlik ve makyavelizmin örgüt yararına ahlaki olmayan davranış üzerinde etkisi: ahlaki iklimin düzenleyici rolü.

Coulter, A., \& Ellins, J. (2007). Effectiveness of strategies for informing, educating, and involving patients. Bmj, 335(7609), 24-27.

Curtis-Tweed*, P. (2004). Moral and civic responsibility and the commercialization of higher education. Journal of Moral Education, 33(2), 211-217.

Demirbaş, N. (2010). Yaşamda anlam ve yılmazlık. (Yayınlanmamış yüksek lisans tezi). Hacettepe Üniversitesi Sosyal Bilimler Enstitüsü, Ankara.

Duman, B. (2021). Üniversite öğrencilerinin özgecilik düzeyleri ile sosyodemografik değişkenler açısından incelenmesi. Balkan ve Yakın Doğu Sosyal Bilimler Dergisi, 7(4), 27-35.

Duru, A., \& Reeb, D. M. (2002). International diversification and analysts' forecast accuracy and bias. The Accounting Review, 77(2), 415-433.

Eagly, A. H., \& Crowley, M. (1986). Gender and helping behavior: A meta-analytic review of the social psychological literature. Psychological Bulletin, 100(3), 283.

Edwards, P. (1972). Why, in the encyclopedia of philosophy? (ed. P. Edwards), Vol: 6-7, 296-302. Macmillan Publishing Company

Egilmez, E., \& Naylor-Tincknell, J. (2017). Altruism and popularity. International Journal of Educational Methodology, 3(2), 65-74.

Ekşi, H., Sayın, M. \& Çelebi, Ç. D. (2016). Üniversite öğrencilerinin özgecilik ve otantiklik seviyeleri arasindaki ilişkinin incelenmesi. Değerler Eğitimi Dergisi 14 (32), 79-102.

Erikson, E. (1968). Youth: identity and crisis. New York, NY: WW. https://Doi.Org/10.1002/yd.29.

Farsides, T. (2007). The psychology of altruism. Psychologıst- Leıcester-, 20(8),474.

Fehr, E., \& Fischbacher, U. (2003). The nature of human altruism. Nature, 425(6960), 785-791. 
Feinberg, J. (1980). Absurd self-fulfillment. In Time and Cause (pp. 255-281). Springer.

Fortin, N. M. (2006). Greed, altruism, and the gender wage gap. Unpublished manuscript, Department of Economics, University of British Columbia.

Frankfurt, H. G. (2009). The reasons of love. Princeton University Press.

Freeman, D., Aquino, K., \& McFerran, B. (2009). Overcoming beneficiary race as an impediment to charitable donations: social dominance orientation, the experience of moral elevation, and donation behavior. Personality and Social Psychology Bulletin, 35(1), 72-84.

Freedman, J. L., Sears, D. O. \& Carlsmith, J. S. M. (1993). Sosyal psikoloji. (Çev.: A. Dönmez). Ankara: İmge Kitapevi.

Griskevicius, V., Tybur, J. M., \& Van den Bergh, B. (2010). Going green to be seen: status, reputation, and conspicuous conservation. Journal of Personality and Social Psychology, 98(3), 392. https://Doi.Org/10.1037/a0017346.

Hamilton, W. D. (1972). Altruism and related phenomena, mainly in social insects. Annual Review of Ecology and Systematics, 3(1), 193-232. https://doi: 10.1146/annurev.es.03.110172.001205.

Han, H. (2015). Purpose as a moral virtue for flourishing. Journal of Moral Education, 44(3), 391-309. https://Doi.Org/10.1080/03057240.2015.1040383.

Han, H. (2015). Virtue ethics, positive psychology, and a new model of science and engineering ethics education. Science and Engineering ethics, 21(2), 441-460. https://Doi.Org/10.1007/s11948-0149539-7

Han, H., Liauw, I., \& Kuntz, A. F. (2019). Moral identity predicts the development of presence of meaning during emerging adulthood. Emerging Adulthood, 7(3), 230-237.

https://doi.org/10.1177/2167696818758735

Hardy, S. A., \& Carlo, G. (2011). Moral identity: What is it, how does it develop, and is it linked to moral action? Child Development Perspectives, 5(3), 212-218. https://doi.org/10.1111/j.17508606.2011.00189.x

Hardy, S. A., Francis, S. W., Zamboanga, B. L., Kim, S. Y., Anderson, S. G., \& Forthun, L. F. (2013). The roles of identity formation and moral identity in college student mental health, health-risk behaviors, and psychological well-being. Journal of Clinical Psychology, 69(4), 364-382. https://Doi.Org/10.1002/jclp.21913.

Hardy, S. A., Walker, L. J., Olsen, J. A., Woodbury, R. D., \& Hickman, J. R. (2014). Moral identity as moral ideal self: links to adolescent outcomes. Developmental Psychology, 50(1), 45-57. https://Doi.Org/10.1037/a0033598.

Harris, M. B., \& Bays, G. (1973). Altruism and sex roles. Psychological Reports, 32(3, Pt 1), 1002. https://doi.org/10.2466/pr0.1973.32.3.1002

Hart, D. (2005, January). The development of moral identity. In Nebraska symposium on motivation (Vol. 51, p. 165).

Hicks, J. A., \& King, L. A. (2007). Meaning in life and seeing the big picture: positive affect and global focus cognition and emotion. Psychology Press, 21(7), 1577-1584 https://doi.org/10.1080/02699930701347304

Hoffman, M. L. (1977). Empathy, its development and prosocial implications. In Nebraska symposium on motivation. University of Nebraska Press.

Hooker, B. (2008). The meaning of life: Subjectivism, objectivism, and divine support. In The Moral Life (pp. 184-200). Palgrave Macmillan. 
İşmen, E. ve Yıldız, A. (2005). Öğretmenliğe ilişkin tutumların özgecilik ve atılganlık düzeyleri açısından incelenmesi. Kuram ve Uygulamada Eğitim Yönetimi, 11(42), 151-166.

James, L. (2005). Achievement and the meaningfulness of life. Philosophical Papers, 34, 429-42. https://doi.org/10.1080/05568640509485166

Johnson, K. K. (2000). Age and gender differences in altruistic behavior. unpublished thesis. OR: University of Oregon.

Kaçar-Banbal, G. (2010). Hemşirelik öğrencilerinin özgecilik düzeyleri (Yayınlanmamış yüksek lisans tezi). İstanbul Üniversitesi Sağlık Bilimleri Enstitüsü.

Kamm, F. M. (2003). Rescuing Ivan Ilych: how we live and how we die. Ethics, 113, 202-33.

Kasapoğlu, F. (2013). Üniversite Öğrencilerinde İyilik Hali İle Özgecilik Arasındaki İlişkinin İncelenmesi. Yüksek Lisans Tezi, İnönü Üniversitesi Eğitim Bilimleri Enstitüsü, Malatya.

Kasapoğlu, F. (2014). İyilik hali ile özgecilik arasındaki ilişkinin incelenmesi. Hikmet Yurdu Düşünce-Yorum Sosyal Bilimler Araştırma Dergisi, 7(13), 271-288.

Kiang, L., \& Fuligni, A. J. (2010). Meaning in life as a mediator of ethnic identity and adjustment among adolescents from Latin, Asian, and European American backgrounds. Journal of Youth and Adolescence, 39(11), 1253-1264. https://doi.org/10.1007/s10964-009-9475-z

Klemke, E. D. (2000). The meaning of life. Oxford University Press

Kocabiyik, O. O. (2014). Benlik ve ahlaki kimlik. Değerler Eğitimi Dergisi, 12(27), 261-280.

Krawczyk, M., \& Le Lec, F. (2010). 'Give me a chance!'An experiment in social decision under risk. Experimental Economics, 13(4), 500-511.https://doi.org/10.1007/s10683-010-9253-5

Krebs, C. J. (1970). Genetic and behavioral studies on fluctuating vole populations. In Proc. Adv. Study Inst. Dynamics numbers populations (Oosterbeek) (pp. 243-256).

Krettenauer, T., Murua, L. A., \& Jia, F. (2016). Age-related differences in moral identity across adulthood. Developmental Psychology, 52(6), 972. https://doi.org/10.1037/dev0000127

Kristjánsson, K. (2007). Measuring self-respect. Journal for the Theory of Social Behaviour, 37(3), $225-242$. https://doi.org/10.1111/j.1468-5914.2007.00339.x.

Kumru, A., Carlo, G. \& Edwards, C. P. (2004). Olumlu sosyal davranişlarin ilişkisel, kültürel, bilişsel ve duyuşsal bazi değişkenlerle ilişkisi. Türk Psikoloji Dergisi, 19(54), 109-125.

Le Galliard, J. F., Ferrière, R., \& Dieckmann, U. (2003). The adaptive dynamics of altruism in spatially heterogeneous populations. Evolution, 57, 1-17. https://doi.org/10.1554/0014-3820.

Lennon, M. C., Appelbaum, L. D., Aber, J. L., \& McCaskie, K. (2003). Circumstances dictate public views of government assistance. http://www.nccp.org/publications/pdf/text_552.pdf.

Long, M. C., \& Krause, E. (2017). Altruism by age and social proximity. PloS One, 12(8), e0180411. https://doi.org/10.1371/journal.pone.0180411

Ma, B., Christen, B., Leung, D., \& Vigo-Pelfrey, C. (1992). Serodiagnosis of lyme borreliosis by western immunoblot: reactivity of various significant antibodies against borrelia burgdorferi. Journal of Clinical Microbiology, 30(2), 370-376.

Malin, H., Ballard, P. J., \& Damon, W. (2015). Civic purpose: an integrated construct for understanding civic development in adolescence. Human Development, 58(2), 103-130. https://doi.org/10.1159/000381655. 
Malin, H., Han, H., \& Liauw, I. (2017). Civic purpose in late adolescence: Factors that prevent decline in civic engagement after high school. Developmental Psychology, 53(7), 1384. https://doi.org/10.1037/dev0000322.

Malin, H., Reilly, T. S., Quinn, B., \& Moran, S. (2014). Adolescent purpose development: exploring empathy, discovering roles, shifting priorities, and creating pathways. Journal of Research on Adolescence, 24, 186-199. https://doi.org/10.1111/jora.12051.

Marcus, R. F. (1980). Empathy and popularity of preschool children. Child Study Journal, 10, 133-145. doi: 10.1037/h0081268.

Matsuba, M. K., \& Walker, L. J. (2005). Young adult moral exemplars: The making of self through stories. Journal of research on adolescence, 15(3), 275-297.

King, P. M., \& Mayhew, M. J. (2002). Moral judgement development in higher education: Insights from the Defining Issues Test. Journal of moral education, 31(3), 247-270.

Meca, A., Sabet, R. F., Farrelly, C. M., Benitez, C. G., Schwartz, S. J., Gonzales-Backen, M., ... \& Lizzi, K. M. (2017). Personal and cultural identity development in recently immigrated Hispanic adolescents: Links with psychosocial functioning. Cultural Diversity and Ethnic Minority Psychology, 23(3), 348. https://doi:10.1037/cdp0000129.

Metz, T., (2012). The meaningful and the worthwhile: Clarifying the relationships. The Philosophical Forum, 43, 435-48.

Metz, T. (2013). Meaning in life as the aim of psychotherapy: A hypothesis. In the Experience of Meaning in Life (pp. 405-417). Springer.

Midlarsky, E. (1991). Helping as coping. In M. S. Clark (Ed.), Review of personality and social psychology, Vol. 12. Prosocial Behavior (p. 238-264). Sage Publications, Inc.

Nagel, T. (1978). The Possibility of Altruism, 1970. Princeton (New Jersey).

Negru-Subtirica, O., Pop, E. I., Luyckx, K., Dezutter, J., \& Steger, M. F. (2016). The meaningful identity: a longitudinal look at the interplay between identity and meaning in life in adolescence, Developmental Psychology, 52. (11), 1926-1936. https://doi:10.1037/dev0000176.

Nielsen, K. (1964). Linguistic philosophy and "the meaning of life. Cross Currents, 14(3), 313-334. Oxford University Press.

Nickerson, M. (2003). " The power of a morally indignant woman"-Republican women and the making of California conservatism. Journal of the West, 42(3), 35-43.

Nozick, R. (1974). Anarchy, state and utopia New York: Basic Books.

Onat, O. (2011). Genç yetişkinlerin ahlaki kimliklerinin incelenmesine yönelik nitel bir araştırma (Doctoral dissertation, Marmara Universitesi (Turkey)).

Onatır, M. (2008). Öğretmenlerde Özgecilik İle Değer Tercihleri Arasındaki İlişki. Yüksek Lisans Tezi, Yeditepe Üniversitesi Sosyal Bilimler Enstitüsü, İstanbul.

Özbey, A., \& Karduz, F. F. A. (2018). Özel yetenekli ve normal gelişim gösteren öğrencilerin ahlaki kimlik ve özgecilik düzeylerinin incelenmesi. Abant İzzet Baysal Üniversitesi Eğitim Fakültesi Dergisi, 18(4), 2207-2226.

Park, N., Park, M., \& Peterson, C. (2010). When is the search for meaning related to life satisfaction? Applied Psychology: Health and Well-Being, 2(1), 1-13. https://doi:10.1111/j.1758- 0854.2009.01024.x.

Patrick, R. B., Bodine, A. J., Gibbs, J. C., \& Basinger, K. S. (2018). What accounts for prosocial behavior? Roles of moral identity, moral judgment, and self-efficacy beliefs. The Journal of Genetic Psychology, 179(5), 231-245. https://doi.org/10.1080/00221325.2018.1491472 
Phillips, J., De Freitas, J., Mott, C., Gruber, J., \& Knobe, J. (2017). True happiness: the role of morality in the folk concept of happiness. Journal of Experimental Psychology: General, 146(2), 165-181. https://doi.org/10.1037/xge0000252.

Piliavin, J. A. \& Charng, H. W. (1990). Altruism: a review of recent theory and research. The Annual Review of Sociology, 16, 27-65.

Porter, T. J. (2013). Moral and political identity and civic involvement in adolescents. Journal of Moral Education, 42(2), 239-255. https://doi.org/10.1080/03057240.2012.761133.

Reed, I. I., \& Aquino, K. F. (2003). Moral identity and the expanding circle of moral regard toward outgroups. Journal of personality and social psychology, 84(6), 1270-86. https://doi.org/10.1037/00223514.84.6.1270

Reed, A., Aquino, K., \& Levy, E. (2007). Moral identity and judgments of charitable behaviors. Journal of Marketing, 71(1), 178-193.

Reimer, K., \& Wade-Stein, D. (2004). Moral identity in adolescence: Self and other in semantic space. Identity, 4(3), 229-249.

Reker, G. T., \& Wong, P. T. P. (1988). Aging as an individual process: Toward a theory of personal meaning. In J. E. Birren \& V. L. Bengston (Eds.), Emergent theories of aging (pp. 214-246). NY: Springer.

Rushton, J. P., Fulker, D. W., Neale, M. C., Nias, D. K., \& Eysenck, H. J. (1986). Altruism and aggression: the heritability of individual differences. Journal of personality and social psychology, 50(6), 1192.

Seachris, J. (2009). The meaning of life as narrative: a new proposal for interpreting philosophy's 'primary' question. Philo, 12, 5-23. https://doi.org/10.5840/philo20091211

Seeram, E. (2019). An overview of correlational research. Radiologic technology, 91(2), 176-179.

Smith, C., Christoffersen, K., Davidson, H., \& Herzog, P. S. (2011). Lost in transition: the dark side of emerging adulthood., NY: Oxford University Press.

Steger, M. F., Bundick, M. J., \& Yeager, D. (2011). Meaning in life. In R. J. R. Levesque (Ed.), Encyclopedia of Adolescence (pp. 1666-1677). New York, NY: Springer New York. https://doi.org/10.1007/978-14419-1695-2_316.

Steger, M. F., Frazier, P., Oishi, S., \& Kaler, M. (2006). The meaning in life questionnaire: assessing the presence of and search for meaning in life. Journal of Counseling Psychology, 53(1), 80-93. https://doi.org/10.1037/0022-0167.53.1.80.

Steger, M. F., \& Kashdan, T. B. (2007). Stability and specificity of meaning in life and life satisfaction over one year. Journal of Happiness Studies, 8(2), 161-179. https://doi.org/10.1007/s10902-006-9011-8.

Steger, M. F., Kashdan, T. B., \& Oishi, S. (2008). Being good by doing good: daily eudemonic activity and well-being. Journal of Research in Personality, 42, 22-42. https://doi.org/10.1016/j.jrp.2007.03.004.

Steger, M. F., Kashdan, T. B., Sullivan, B. A., \& Lorentz, D. (2008). Understanding the search for meaning in life: personality, cognitive style, and the dynamic between seeking and experiencing meaning. Journal of Personality, 76(2), 199-228. https://doi.org/10.1111/j.1467-6494.2007.00484.x.

Steger, M. F., Oishi, S., \& Kashdan, T. B. (2009). Meaning in life across the life span: levels and correlates of meaning in life from emerging adulthood to older adulthood. The Journal of Positive Psychology, 4(1), 43-52. https://doi.org/10.1080/17439760802303127.

Stets, J. E., \& McCaffree, K. (2014). Linking morality, altruism, and social solidarity using identity theory. In the palgrave handbook of altruism, morality, and social solidarity (pp. 333-351). Palgrave Macmillan. 
Stets, Jan E. \& Michael J. Carter. (2011). The moral self: applying identity theory. Social Psychology Quarterly 74, 192-215. https://doi.org/10.1177/0190272511407621

Stets, Jan E. \& Michael J. Carter. (2012). A theory of the self for the sociology of morality. American Sociological Review 77, 120-140. https://doi.org/ 10.1177/0003122411433762

Stockard, J. (2006). Gender socialization. In Handbook of the Sociology of Gender (pp. 215-227). Springer, Boston, MA.

Strohminger, N., \& Nichols, S. (2014). The essential moral self. Cognition, 131(1), 159-171. https://doi: 10.1016/j.cognition.2013.12.005.

Tabachnick, B. G., \& Fidell, L. S. (2013). Using multivariate statistics (6th Ed.). Boston MA: Pearson.

Taş, İ. (2011). Öğretmenlerde yaşamın anlamı yaşam doyumu sosyal karşılaştırma ve iç-dış kontrol odağının çeşitli değişkenler açısından incelenmesi (Yayımlanmamış yüksek lisans tezi). Sakarya Üniversitesi, Sakarya.

Taylor, C. (1992). The ethics of authenticity. MA: Harvard University Press.

Thomas, L. (2005). Morality and a meaningful life. Philosophical Papers, 34, 405-27.

Trisel, B. A. (2002). Futility and the meaning of life debate. Sorites, 14, 70-84.

Uğur, E. \& Akın, A. (2015). Yaşam bağlılığı ölçeği Türkçe formu: Geçerlik ve güvenirlik çalışması. İnsan ve Toplum Bilimleri Araştırmaları Dergisi, 4(2), 424-432.

Ümmet, D., Halii, E. K. Ş. İ., \& Otrar, M. (2013). Özgecilik (altruism) ölçeği geliştirme çalışması. Değerler Eğitimi Dergisi, 11(26), 301-321.

Ünal, A. (2015). İş doyumu, yaşam doyumu ve yaşam anlamı değişkenlerinin ilkokul ve ortaokul öğretmenlerinin mesleki bağlılıkları üzerine etkisi (Yayımlanmamış yüksek lisans tezi). Ondokuz Mayıs Üniversitesi Eğitim Bilimleri Enstitüsü.

Velleman, J. D. (2005). Family history. Philosophical Papers, 34, 357-78.

Verkasalo, M., Tuomtvaara, P., \& Lindeman, M. (1996). 15-year-old Pupils' and their Teachers' Values, and their Beliefs about the Values of an Ideal Pupil. Educational Psychology, 16(1), 35-47.

Walker, L. J. (1999). The perceived personality of moral exemplars. Journal of Moral Education, 28(2), 145162.

Walker, L. J. (1984). Sex differences in the development of moral reasoning: A critical review. Child Development, 677-691. https://doi.org/10.2307/1130121

Walker, L. J. ve Frimer, J. A. (2007). Moral personality of brave and caring exemplars. Journal of Personality and Social Psychology, 93(5), 845- 860. https://doi.org/10.1037/0022-3514.93.5.845

Ward, T., \& Durrant, R. (2013). Altruism, empathy, and sex offender treatment. International Journal of Behavioral Consultation and Therapy, 8(66-71), 66.

Wohlgennant, R. (1981). Has the question about the meaning of life any meaning? repr. Life and Meaning: A Reader, 1987, 34-38.

Wolf, S. (2010). Meaning in life and why it matters. Princeton University Press.

Yalom, I. (2001). Varoluşçu psikoterapi (Z. İ. Babayiğit, Çev.). Kabalcı Yayınevi.

Yang, L., Cai, G., Yong, S., \& Shi, H. (2020). Moral identity: A mediation model of moral disengagement and altruistic attitude. Social Behavior and Personality: an international journal, 48(7), 1-13. 
Yeşilkayalı, H. C. (2015). Koruyucu Aile Bireylerinin Sosyodemografik Özellikleri ile Empatik Becerileri Ve Özgecilik Durumları Arasındaki Illişkinin İncelenmesi. Yayımlanmamış Yüksek Lisans Tezi, Ankara Üniversitesi Sağlık Bilimleri Enstitüsü, Ankara.

Yıkılmaz, M. ve Demir-Güdül, M. (2015). Üniversite öğrencilerinde yaşamda anlam, bilinçli farkındalık, algılanan sosyoekonomik düzey ve yaşam doyumu arasındaki ilişkiler. Ege Eğitim Dergisi, 16(2), 297315.

Yılmaz, A. G. F., \& Yılmaz, A. G. F. (2015). Ahlaki kimlik ölçeği Türkçe formunun geçerlik ve güvenirlik çalışması. Celal Bayar Üniversitesi Sosyal Bilimler Dergisi, 13(4), 111-134. https://doi.org/10.18026/cbusos.35372

Yüksel, R. (2013). Genç yetişkinlerde aşk tutumları ve yaşamın anlamı (Yayımlanmamış yüksek lisans tezi). Eğitim Bilimleri Enstitüsü, Sakarya Üniversitesi.

Zika, S., \& Chamberlain, K. (1992). On the relation between meaning in life and psychological well-being. British Journal of Psychology, 83, 133-145. https://doi.org/10.1111/j.2044-8295.1992.tb02429.x 


\section{Öğretmen Adaylarunda Ahlaki Kimlik, Özgecilik Ve Yaşamun Anlamı}

\author{
Dr.Öğrt. Üyesi Fatıma Firdevs Adam Karduz \\ Cumhuriyet Üniversitesi - Türkiye \\ ORCID: 0000-0003-1765-6287 \\ karduzfirdevs@cumhuriyet.edu.tr
}

\author{
Dr. Adnan Özbey \\ University of North Texas - USA \\ ORCID: 0000-0002-5198-8026 \\ adnanozbey@hotmail.com
}

\begin{abstract}
Özet
Bu araştırmada, öğretmen adaylarının yaşamın anlamı, ahlaki kimlik ve özgecilik düzeyleri arasındaki olası ilişki durumu ile bazı değişkenlere göre farklılık gösterip göstermediklerini tespit etmek amaçlanmıştır. Bu araştırmada, nicel araştırma yöntemlerinden genel tarama modelinin bir alt türü olan ilişkisel tarama modeli kullanılmıştır. Araştırmanın örneklemi için 2017-2018 eğitim öğretim yılında İmir ve Manisa illerinde eğitime devam eden 209 (\% 55,9) 4. sınıf ve mezun olmuş 166 (\% 44,1) toplamda 375 ögretmen adayına ulaşılmıştır. Veri toplama aracı olarak; Steger ve diğerleri (2006) tarafından geliştirilen Yaşamın Anlamı Ölçeği; Aquino ve Reed (2002) tarafından bireylerin ahlaki kimlik düzeylerini ölçmeye yönelik geliştirilen Ahlaki Kimlik Ölçeği ve Ümmet, Ekşi ve Otrar (2013) tarafından bireylerin özgecilik düzeylerini ölçmeye yönelik geliştirilmiş Özgecilik (Altruism) Ölçeği kullanılmıştır. Çalışmada; Öğretmen adaylarının ahlaki kimlik, yaşamın anlamı ve özgecil davranış tutumları cinsiyete göre istatistiksel olarak anlamlı düzeyde farklılaşmakta mıdır? Öğretmen adaylarının ahlaki kimlik, yaşamın anlamı ve özgecil davranış tutumları mezuniyet durumuna göre istatistiksel olarak anlamlı düzeyde farklılaşmakta mıdır? Öğretmen adaylarının ahlaki kimlik, yaşamın anlamı ve özgecil davranış tutumları arasında istatistiksel olarak anlamlı bir ilişki var mıdır? Öğretmen adaylarının ahlaki kimlik ve özgecil davranıs tutumları; yaşamın anlamını istatistiksel olarak anlamlı düzeyde yordamakta mıdır? sorularına cevap aranmıştır. Sonuç olarak, öğretmen adaylarının ahlaki kimlik ve özgecilik düzeylerinin istatistiksel olarak anlamlı bir şekilde hayatın anlamının yordayıcıları olduğu bulunmuştur.
\end{abstract}

Anahtar Kelimeler: Ahlaki Kimlik, Özgecilik, Yaşamın Anlamı, Öğretmen.

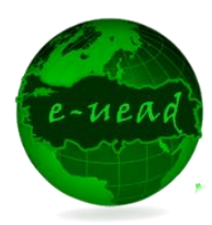

E-Uluslararası Eğitim Araștırmaları Dergisi

Cilt: 12 , No: 5, ss. $65-88$

Araştırma Makalesi
Gönderim: 2021-09-26 Kabul: 2021-11-08

\section{Önerilen Atıf}

Adam Karduz, F.F. \& Ozbey, A. (2021). Öğretmen Adaylarında Ahlaki Kimlik, Özgecilik ve Yaşamın Anlamı, EInternational Journal of Educational Research, 12(5), 65-88. DOI: https://doi.org/10.19160/eijer.1001101 


\section{Genişletilmiş Özet}

Problem: Bu araştırma öğretmen adaylarında ahlaki kimlik, yaşamın anlamı ve özgecil davranış tutumlarını farklı değişkenlere göre incelemektir. Bu amaç doğrultusunda aşağıdaki sorulara cevap aranmıştır:

1. Öğretmen adaylarının ahlaki kimlik, yaşamın anlamı ve özgecil davranış tutumları cinsiyete göre istatistiksel olarak anlamlı düzeyde farklılaşmakta mıdır?

2. Öğretmen adaylarının ahlaki kimlik, yaşamın anlamı ve özgecil davranış tutumları mezuniyet durumuna göre istatistiksel olarak anlamlı düzeyde farklılaşmakta mıdır?

3. Öğretmen adaylarının ahlaki kimlik, yaşamın anlamı ve özgecil davranış tutumları arasında istatistiksel olarak anlamlı bir ilişki var mıdır?

4. Öğretmen adaylarının ahlaki kimlik ve özgecil davranış tutumları; yaşamın anlamını istatistiksel olarak anlamlı düzeyde yordamakta mıdır?

Yöntem: Bu araştırmada, nicel araştırma yöntemlerinden genel tarama modelinin bir alt türü olan ilişsisel tarama modeli kullanılmıştır. Genel tarama modelleri çok sayıda elemandan oluşan bir evrende, evren hakkında genel bir yargıya varmak amacı ile evrenin tümü ya da ondan alınacak bir grup, örnek ya da örneklem üzerinde yapılan tarama düzenlemeleridir. Genel tarama modelleri ile tekil ya da ilişkisel taramalar yapılabilir. ilişskisel tarama modeli, iki ve daha çok sayıdaki değişken arasında birlikte değişim varlı̆ı̆ı ve/veya derecesini belirlemeyi amaçlayan araştırma modelleridir (Büyüköztürk et al., 2015). Bu araştırmada ise öğretmen adaylarının yaşamın anlamı, ahlaki kimlik ve özgecilik düzeyleri arasındaki olası ilişki durumu ile bazı değişkenlere göre farklılı gösterip göstermediklerini tespit etmek amaçlanmıștır. Veri toplamak için uygun örnekleme yöntemi seçilmiştir. Uygun örneklem yöntemi; zaman, para ve işgücü kaybını önlemek amacıyla örneklemin kolay ulaşılabilir ve uygulama yapılabilir birimlerden seçilmesidir (Büyüköztürk ve diğ. 2015). Bu amaçla Izmir ve Manisa illerinde eğitime devam eden 209 (\% 55,9) 4. sınıf ve mezun olmuş 166 (\% 44,1) toplamda 375 öğretmen adayına ulaşılmıştır.

Bulgular: Karşılaştırma Analizleri ve ilişki bulguları şeklinde iki başlıkta sunulmuştur:

Karşılaştırma Analizleri: Öğretmen adaylarının yaşamın anlamı, ahlaki kimlik ve özgecilik düzeylerinin cinsiyet değişkenine göre karşılaştırmak için bağımsız örneklem t testi kullanılmıştır. Kadın ögretmen adaylarının yaşamın anlamı puanları ortalamaları $(\bar{x}=51.16)$ ile erkek öğretmen adaylarının yaşamın anlamı puan ortalamaları $(\bar{x}=51.62)$ arasında istatistiksel olarak anlamlı bir farkllık yoktur $(t=-, 484, p<.05)$. Benzer şekilde kız ögretmen adaylarının ahlaki kimlik puan ortalamaları $(\bar{x}=53.46)$ ile erkek öğretmen adaylarının ahlaki kimlik puan ortalamaları $(\bar{x}=51,90)$ arasında istatistiksel olarak anlamlı bir farklılı yoktur $(t=1,418, p<.05)$. Diğer yandan kız ögretmen adaylarının özgecilik puan ortalamaları ( $\bar{x}=38.91)$ erkek öğretmen adaylarının özgecilik puan ortalamalarından $(\bar{x}=37,22)$ istatistiksel olarak anlamlı bir şekilde yüksektir $(t=2,908, p<.05)$.

Mezun öğretmen adaylarının yaşamın anlamı puanları ortalamaları $(\bar{x}=52.77)$ dördüncü sınıf ögretmen adaylarının yaşamın anlamı puan ortalamalarından $(\overline{\mathrm{x}}=50.27)$ istatistiksel olarak anlamlı bir şekilde yüksektir ( $t=-2,674, p<.05)$. Dördüncü sınıf öğretmen adaylarının ahlaki kimlik puan ortalamaları $(\bar{x}=52.17)$ ile mezun sını öğretmen adaylarının ahlaki kimlik puan ortalamaları $(\bar{x}=53.46)$ arasında istatistiksel olarak anlamlı bir farkllık yoktur $(t=-1,170, p<.05)$. Benzer şekilde dördüncü sınıf ögretmen adaylarının özgecilik puan ortalamaları $(\bar{x}=38.32)$ ile mezun sınıf ögretmen adaylarının özgecilik puan ortalamaları $(\bar{x}=37,88)$ arasında istatistiksel olarak anlamlı bir farklılı yoktur ( $t=.731, p<.05)$.

ilişki Bulguları: Öğretmen adaylarında yaşamın anlamı, ahlaki kimlik ve özgecilik arasında ilişki olup olmadığını saptamak için Pearson momentler çarpımı ilgileşim analizi uygulanmıştır. 
Yaşamın anlamı, ahlaki kimlik ve özgecilik arasında $p<.01$ eşiğinde pozitif yönlü istatistiksel olarak anlamlı ilgileşim mevcuttur. Buna göre yaşamın anlamı ile ahlaki kimlik arasında ilgileşim katsayısı $r=44$; yaşanın anlamı ile özgecilik arasında ilgileşim katsayısı $r=.30$; ahlaki kimlik ve özgecilik arasında ilgileşim katsayısı $r=.28$ olarak tespit edilmiştir.

Yaşamın anlamını yordamada ahlaki kimlik ve özgecilik değişkeninin rolünü görmek için yapılan regresyon analizinde, ahlaki kimlik ve özgecilik değişkeninin yaşamın anlamını istatistiksel olarak anlamlı bir şekilde yordadığı görülmektedir $(F=53,105, p<.001, R=.48, R 2=.23$, Adj R2 $=.22)$. Bu analiz sonuçlarına göre, değişkenlerin varyansa katkısı \% 22'dir. Ahlaki kimlik ve özgeciliğin varyansa katkısı anlamlı (Ahlaki Kimlik: $\beta=.381, t=7,911$; Özgecilik: $\beta=.199, t=4,129$, $p$ <.001) bulunmuştur.

Sonuç: Yapılan bu çalışmada öğretmen adaylarında ahlaki kimlik, yaşamın anlamı ve özgecil davranış tutumlarını farklı değişkenlere göre incelemek amacıyla elde edilen bulgular değerlendirilmiştir.

Ilk olarak, öğretmen adaylarının ahlaki kimlik, yaşamın anlamı ve özgecil davranış tutumları cinsiyete göre değerlendirilmesinde; kı öğretmen adaylarının yaşamın anlamı puan ortalamaları ile erkek ögretmen adaylarının yaşamın anlamı puan ortalamaları arasında istatistiksel olarak anlamlı bir farklıı bulunmamaktadır. Yani hayatın anlamı cinsiyete göre farklılı göstermemektedir. Aynı şekilde kadın öğretmen adaylarının ahlaki kimlik puan ortalamaları ile erkek ögretmen adaylarının ahlaki kimlik puan ortalamaları arasında istatistiksel olarak anlamlı bir farklıık bulunmamıştır. Kadın öğretmen adaylarının özgecilik puan ortalamaları erkek öğretmen adaylarının özgecilik puan ortalamalarından istatistiksel olarak anlamlı bir şekilde yüksek olduğu görülmüştür. Yani yaşamın anlamının, her bir kişsinin değişken zihinsel durumlarına bağlı olarak kişiden kişiye değiştiği varsayılabilir. Genel olarak kişinin (kadın-erkek farketmeksizin), güçlü bir şekilde istediği şeyi alması, yüksek dereceli hedeflerine ulaşması veya gerçekten önemli olduğuna inandığı şeyi yapması (Trisel 2002; Hooker 2008; Alexis 2011) hayatını daha anlamlı kılmasına sebep olabilir. Subjektivist bakış açısına göre de, eğer kişi zihinsel olarak bir durumu umursuyor ya da seviyorsa, o zaman kişi için yaşamın umursadığı ya da sevdiği ölçüde anlamlı olmaktadır (Frankfurt, 2009).

ikinci olarak, öğretmen adaylarının ahlaki kimlik, yaşamın anlamı ve özgecil davranış tutumları mezuniyet durumuna göre değerlendirildiğinde; mezun öğretmen adaylarının yaşamın anlamı puan ortalamaları dördüncü sınıf ögretmen adaylarının yaşamın anlamı puan ortalamalarından istatistiksel olarak anlamlı bir şekilde yüksek olduğu görülmektedir. Ancak dördüncü sınıf öğretmen adaylarının ahlaki kimlik puan ortalamaları ile mezun sınıf öğretmen adaylarını ahlaki kimlik puan ortalamaları arasında istatistiksel olarak anlamlı bir farklılı bulunmamıştır. Benzer şekilde dördüncü sınıf ögretmen adaylarının özgecilik puan ortalamaları ile mezun sınıf ögretmen adaylarının özgecilik puan ortalamaları arasında istatistiksel olarak anlamlı bir farklılık yoktur. Prososyal davranışın iki önemli şekli vardır. Bunlardan biri de özgeciliktir. Özgeci davranışı gösteren kimsenin belli bir bedel ödemesi söz konusudur. Ancak bu bedelin karşılığında kişisel çıkar beklentisi olmadan özgecil davranışın yapılmasıdır (Bilgin, 2020). Genel olarak, kimlik araştırması sonucunda, çoğu insanın hem özgecil hem de gayrıresmi davranışları göz önüne alırken ahlaki bir şekilde hareket ettiğini bildirmiştir (Stets \& Carter 2011; 2012).

Son olarak, ögretmen adaylarının yaşamın anlamını yordama da ahlaki kimlik ve özgecilik değişkeninin rolünü görmek için yapılan regresyon analizinde, ahlaki kimlik ve özgecilik değişkeninin yaşamın anlamını istatistiksel olarak anlamlı bir şekilde yordadığı görülmektedir. Bu analiz sonuçlarına göre, değişkenlerin varyansa katkısı \% 22'dir. Ahlaki kimlik ve özgeciliğin varyansa katkısı anlamlı bulunmuştur. Yani, yaşamdaki anlamın var olmasındaki faktörlerin, kişinin hayatını anlamlı kılan şeyin içeriği üzerinde olumlu yada olumsuz bir etkisinin olmamasıdır (Steger et al., 2006). Başka bir deyişle, gençler hayatlarının anlamını, yıldız bir atlet veya öğrenci olarak anlam bulmak gibi, herhangi bir ahlaki amaca yönelik olmayan şekillerde inşa edebilir. Dolayısıla, 
yalnızca anlamın varlığı mutlaka ahlaki kimliği tanımlamaz. Bununla birlikte, ahlaki bir kimlik geliştirmek yaşamın anlamının varlığını öngörmektedir (Han, Liauw ve Kunt, 2019). Yıkılmaz ve Demir-Güdül (2015) yaptıkları araştırmada üniversite öğrencilerinde bilinçli farkındalığın ve yaşamda anlam varlığının yaşam doyumunu anlamlı düzeyde yordadığını, anlam arayışının ise yaşam doyumunun anlamlı bir yordayıcısı olmadığını göstermektedir. Ahlaki davranış toplumda düzeni, emniyeti sağlar (Stets\& McCaffree, 2014).

Öneriler: Bu çalışma 4. Sınıf üniversite öğrencileri ve mezun öğretmen adaylarıyla sınırlıdır. Yani elde edilen bulguları diğer üniversite eğitim düzeyi ve meslek gruplarına genellemek mümkün değildir. Çeşitli değişkenlerle benzer çalışmalar üniversitelerin farklı bölümüne devam eden diğer sınıf düzeylerindeki öğrenciler ve meslek gruplarıyla karşılaştırma yapılması konuya farklı bakış açları getirecektir. Alanda aktif olarak görev yapan psikolojik danışmanlar, psikologlar, sosyal hizmet uzmanları hazırlayacakları eğitim programları veya seminerlerde bu bulguları kullanarak üniversite öğrencileri ve mezun meslek adaylarını bilgilendirerek farkındalıklarını artırıp bilinçlenmelerini sağlayabilirler. 